\title{
PERGESERAN ORIENTASI PENELITIAN HUKUM: DARI DOKTRINAL KE SOSIO-LEGAL
}

\author{
Muhammad Helmy Hakim \\ Fakultas Syariah dan Ekonomi Islam Institut Agama Islam Negeri (IAIN) Antasari Banjarmasin \\ Jalan A. Yani Km. 4.5 Banjarmasin Kalimantan Selatan \\ e-mail:mh.hakim@ymail.com
}

\begin{abstract}
:
Abstrak: Penelitian hukum doktrinal dalam pendidikan tinggi akan lebih diperkaya jika menyediakan sedikit ruang bagi penelitian hukum sosio-legal yang bersifat interdisipliner. Pendekatan ini akan membantu menemukan dan menjelaskan keterkaitan hukum dan masyarakat. Dengan demikian diharapkan akan lahir para sarjana profesional yang tidak hanya paham tentang ilmu hukum, tetapi juga insan hukum yang dapat berfungsi maksimal karena paham tentang sendi-sendi keadilan masyarakatnya sendiri. Oleh karenanya dibutuhkan suatu pendekatan hukum yang bisa menjelaskan hubungan antara hukum dan masyarakat, maka pendekatan socio-legal merupakan salah satu alternatifnya
\end{abstract}

Kata Kunci: Hukum, penelitian, socio-legal, masyarakat, doktrinal

\section{Pendahuluan}

Selama ini banyak sekali kritik yang ditujukan kepada mahasiswa maupun sarjana fakultas hukum (termasuk juga mahasiswa dan sarjana fakultas Syari'ah) yang dinisbahkan sebagai kaku, kering, sangat normatif dan preskriptif. Dalam benak mereka hanyalah hukum-hukum halal dan haram, sah dan tidak sah tanpa penjelasan metodologi penemuan hukum yang valid dan memadai. Dengan fasih mereka mengutip pasalpasal aturan perundang-undangan ataupun nashnash al Qur'an dan hadits-hadits, namun mereka gagap dalam mengaplikasikannya terhadap kasus yang kongkret dan kompleks. Kesimpulan mereka seringkali meloncat-loncat (jumping conclusion), menyederhanakan masalah, tidak argumentatif. Becher ${ }^{1}$ memberikan deskripsi bagaimana impresi kalangan ilmuwan terhadap akademisi hukum yang digambarkan sebagai 'tidak benar-benar akademis ..., misterius, terasing dan aneh, hanya tempelan semata dalam dunia akademis ..., tidak dapat dipercaya, tidak bermoral, sempit dan arogan'.

Kritik ini semakin menggema terutama dalam bidang penelitian hukum. Para peneliti hukum

\footnotetext{
1 T. Becher, "Towards a Definition of Disciplinary Cultures," Studies in Higher Education 6(1981).
}

seringkali harus bersusah payah menjelaskan sifat keilmuan dan keilmiahan dari kegiatan penelitian mereka kepada koleganya dari disiplin ilmu yang lain. Hasil-hasil penelitian mereka seringkali dinilai sebagai '... tidak menarik, tidak kreatif, dan terdiri dari serangkaian teka-teki intelektual yang tersebar tidak beraturan dalam banyak deskripsi. ${ }^{2}$

Di University of Chicago, dua orang ilmuwan sosial terkemuka Epstein dan King telah menganalisis semua artikel dalam jurnal ilmiah American law review yang diterbitkan antara tahun 1990 dan 2000 yang mengandung kata 'empiris' dalam judulnya. Kesimpulan mereka sangat mengecilkan hati, bahwa ternyata penelitian empiris yang dilakukan oleh para penulis jurnal tersebut hanyalah menerapkan kaidah dasar dari sebuah penelitian empiris. ${ }^{3}$ Kenyataan ini

\footnotetext{
2 Paul Chynoweth, "Legal Research," in Advanced Research Methods in the Built Environment, ed. Andrew Knight and Leslie Ruddock (Chichester, West Sussex, United Kingdom ; Ames, Iowa: Wiley, 2008), 28.

3 Ian Dobinson and Francis Johns, "Qualitative Legal Research," in Research Methods for Law, ed. Mike McConville and Wing Hong Chui (Edinburgh Edinburgh University Press, 2007).
} 
menurut Epstein dan King disebabkan banyak akademisi hukum tidak terlatih dan kurang berpengalaman ketika melaksanakan penelitian empiris dan hanya menguasai kaidah umum yang berlaku untuk penelitian tersebut. Hal ini sebagian besar disebabkan oleh lemahnya pendidikan dan pengajaran tentang penelitian hukum ketika mereka masih berpredikat sebagai mahasiswa.

Bagaimana dengan penelitian hukum di Indonesia? Menurut pengamatan Prof. Dr. Sulistyowati Irianto, Dekan Sekolah Pascasarjana Multidisipliner, Universitas Indonesia, pengajaran metodologi penelitian ilmu hukum di Indonesia pada umumnya masih lemah. Menurut beliau, akademisi hukum di Indonesia masih berada dalam proses pencarian identitas metode penelitiannya sampai hari ini. Mereka masih mencari seperti apakah metode ilmu hukum yang 'benar'? ${ }^{4}$ Persoalan ini menjadi semakin mengemuka jika dikaitkan dengan penelitian hukum empiris di masyarakat. Sebagian akademisi hukum mempertanyakan bagaimanakah metode penelitian ilmu hukum murni yang tidak tercemar metode ilmu sosial. Pertanyaan ini muncul, setidaknya karena ketidakjelasan persoalan kedudukan paradigmatik ilmu hukum dalam universe teori ilmu-ilmu sosial maupun humaniora (meta metodologi) di kalangan akademisi hukum. ${ }^{5}$

Pengamatan di atas menimbulkan pertanyaan penting tentang kualitas penelitian hukum kita. Tetapi makalah ini tidak bertujuan untuk bergabung atau menganalisis perdebatan tentang kualitas penelitian hukum di institusi kita. Makalah ini hanya bermaksud memberikan paparan tentang pergeseran orientasi dalam penelitian hukum dan masyarakat dari doktrinal ke socio legal. Tulisan ini diawali dengan gambaran umum taksonomi penelitian hukum dan dilanjutkan dengan kecenderungan peralihan paradigma penelitian hukum dari monodisipliner ke interdisipliner.

\section{Taksonomi Penelitian Hukum}

Dalam sejarah penelitian hukum, dikenal 2 (dua) tradisi penelitian. ${ }^{6}$ Yang pertama adalah penelitian hukum doktrinal (black-letter law), yang

\footnotetext{
${ }^{4}$ Sulistyowati Irianto, "Praktik Penelitian Hukum: Perspektif Sosiolegal," in Metode Penelitian Hukum: Konstelasi \& Refleksi, ed. Sulistyowati Irianto and Shidarta (Jakarta: Yayasan Obor Indonesia, 2011).

Ibid.

${ }^{6}$ Mike McConville and Wing Hong Chui, eds., Research Methods for Law (Edinburgh: Edinburgh University Press,2007).
}

memfokuskan penelitiannya pada hukum itu sendiri sebagai kaidah yang berdiri sendiri, yang dapat ditelusuri melalui teks-teks hukum dan statuta-statuta, dengan sedikit (bahkan 'tanpa') referensi terhadap disiplin ilmu lainnya. Sedangkan yang kedua adalah 'hukum dalam konteks' (law in context $)^{7}$ yang muncul dan berkembang di sekitar akhir tahun 1960-an. Penelitian hukum doktrinal hanya berfokus pada hukum di buku (law in books). Sedangkan isu-isu seperti penegakan hukum, reformasi hukum, politik hukum dan lain-lain menjadi isu marginal. Sebaliknya dalam ranah 'hukum dalam konteks' (law in context), tumpuan awalnya bukanlah hukum, melainkan persoalanpersoalan yang muncul di masyarakat. Dalam kaitan ini, hukum dilihat sebagai sebuah fenomena sosial yang bisa saja menjadi pemicu munculnya problema sosial atau bisa juga menjadi salah satu bagian dari solusi, bersama-sama dengan aspek-aspek sosial lainnya, seperti politik, ekonomi dan sebagainya.

Begitu halnya dengan perkembangan penelitian hukum di Indonesia, ada dua aliran besar yang saling bertentangan (dualisme). Pada satu pihak, ada kalangan yang ingin menjadikan penelitian hukum sebagai penelitian murni yang lepas dari pengaruh cabang ilmu lainnya (monodisipliner). ${ }^{8}$ Kalangan ini mendorong penggunaan metode-metode sains dalam penelitian hukum agar meningkatkan kadar keilmiahan ilmu hukum. Namun demikian, bagi kalangan ini ilmu hukum bukanlah sains, tetapi dikategorikan sebagai bagian dari humaniora

\footnotetext{
Dalam perkembanganya, kajian tentang hukum dan masyarakat (law and society), mengubah labelnya menjadi kajian sosial tentang hukum atau socio-legal studies. Mengenai hal ini, Tamanaha mengemukakan hasil pengamatannya dengan mengatakan bahwa label atau julukan socio-legal studies juga ditujukan kepada law and society studies. Namun, belakangan istilah yang lebih disukai adalah socio-legal studies. Dengan demikian, istilah socio-legal studies sinonim dengan istilah law and society studies. Lihat Brian Z. Tamanaha, Realistic Socio-Legal Theory Pragmatism and a Social Theory of Law (New York: Oxford University Press, 1997).

8 Lihat Sunaryati Hartono, Penelitian Hukum Di Indonesia Pada Akbir Abad Ke-20 (Bandung: Alumni, 1994); Johnny Ibrahim, Teori Dan Metodologi Penelitian Hukum Normatif (Malang: Bayumedia, 2006); Peter Mahmud Marzuki, Penelitian Hukum (Edisi Revisi), 7 ed. (Jakarta: Prenadamedia Group, 2014). Secara kebetulan, Peter Mahmud Marzuki dan Johnny Ibrahim adalah dua akademisi Universitas Airlangga Surabaya, sehingga sementara ini Universitas Airlangga dikenal sebagai pengawal penelitian hukum doktrinal.
} 
(bumanities) yang normatif. Sedangkan pada pihak lain ada kalangan yang mengkaji hukum sebagai kenyataan dalam kehidupan masyarakat yang untuk memahaminya dilakukan dengan menggunakan berbagai metode dalam disiplin-disiplin ilmu sosial (inter-disipliner).

Soetandyo Wignjosoebroto ${ }^{9}$ membedakan dua pemikiran tersebut sebagai penelitian doktrinal dan penelitian non-doktrinal. Di Indonesia, dualisme tersebut terlanjur disebut dengan penelitian hukum normatif dan satu lagi penelitian hukum empiris. ${ }^{10}$ Penelitian hukum doktrinal menjadikan kaidahkaidah hukum abstrak sebagai ukuran kebenaran dalam studi hukum. Objek dan rujukan yang diacu dalam penelitian doktrinal adalah kaidah-kaidah dari norma, konsep dan doktrin yang berkembang dalam pemikiran hukum. Metode penalaran yang paling acap digunakan dalam penelitian doktrinal ini adalah penalaran silogisme deduktif.

Sedangkan penelitian hukum non-doktrinal menempatkan hasil amatan atas realitas sosial untuk ditempatkan sebagai proposisi umum. Validitas hukum tidak ditentukan oleh norma abstrak yang lahir dari kontruksi pemikiran manusia, melainkan dari kenyataan-kenyataan yang tumbuh dan berkembang dalam masyarakat. Oleh karena itu, untuk memahami hukum dan permasalahannya, berbagai konsep, doktrin dan metode ilmu-ilmu selain ilmu hukum yang bersinggungan dengan masyarakat menjadi bagian integral dalam studi hukum. Selain menggunakan cara deduktif, penelitian non-doktrinal lebih banyak menggunakan cara induktif untuk menampilkan kenyataan.

\footnotetext{
9 Lihat Soetandyo Wignjosoebroto, Hukum: Paradigma, Metode Dan Masalah (Jakarta: ELSAM dan HUMA, 2002); Soetandyo Wignjosoebroto, "Penelitian Hukum Dan Hakikatnya Sebagai Penelitian Ilmiah," in Metode Penelitian Hukum: Konstelasi Dan Refleksi, ed. Sulistyowati Irianto and Shidarta (Jakarta: Yayasan Pustaka Obor Indonesia, 2013); Soetandyo Wignjosoebroto, "RagamRagam Penelitian Hukum," in Metode Penelitian Hukum: Konstelasi Dan Refleksi, ed. Sulistyowati Irianto and Shidarta (Jakarta: Yayasan Pustaka Obor Indonesia, 2013); Sutandyo Wignjosoebroto, "Tentang Teori, Konsep Dan Paradigma Dalam Kajian Tentang Manusia, Masyarakat Dan Hukumnya,"(2015), https: / soetandyo. files.wordpress.com/2010/09/teori_hukum_soetandyo. pdf.

${ }^{10}$ Bandingkan dengan Soerjono Soekanto and Sri Mamudji, Penelitian Hukum Normatif: Suatu Tinjauan Singkat, 3 ed. (Jakarta: Rajawali Press, 1990); Soerjono Soekanto, Pengantar Penelitian Hukum (Jakarta: UI-Press, 2014), 51.
}

Namun sekarang, perkembangan diskursus penelitian hukum telah berkembang sedemikian rupa, dan beranak pinak menjadi cabang-cabang penelitian yang berdiri sendiri. Selain itu, dewasa ini, mahasiswa fakultas hukum semakin berorientasi pada penelitian (more research-based) dan penelitian telah menjadi bagian integral dari kurikulum yang lebih intens dari sebelumnya. Kenyataan ini paling tidak menunjukkan bahwa penelitian hukum sekarang berkembang lebih luas, kompleks dan menuntut keahlian lebih daripada sebelumnya, dan pihak-pihak yang terlibat dalam penelitian dituntut keterampilan dan kompetensi yang lebih mumpuni. ${ }^{11}$ Secara khusus Nonet \& Selznick mendeskripsikan: "Masa dua puluh tahun terakhir ini menjadi bangkitnya kembali ketertarikan pada persoalan-persoalan dalam institusi-institusi hukum, yaitu bagaimana institusi-institusi hukum bekerja, berbagai kekuatan yang mempengaruhinya, serta berbagai keterbatasan dan kemampuannya." 12

Ditengah kompleksitas ragam penelitian ini, Arthurs ${ }^{13}$ memperkenalkan taksonomi penelitian hukum yang sangat berguna bagi pendidikan dan penelitian hukum secara umum. Deskripsi Arthurs ini bisa dilihat pada matriks di bawah ini.

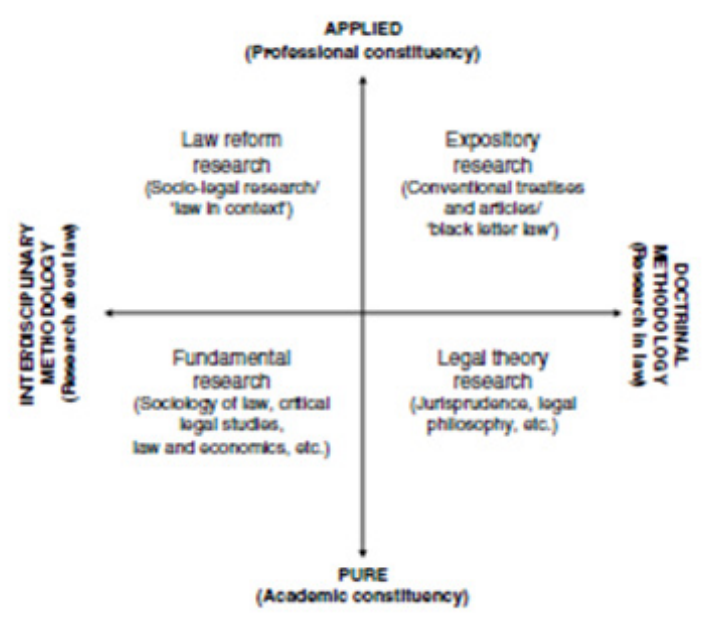

Doktrinal dan Interdisipliner

\footnotetext{
${ }^{11}$ McConville and Chui, eds., Research Methods for Law, 2.

${ }^{12}$ Rikardo Simarmata, "Socio-Legal Studies Dan Gerakan Pembaharuan Hukum," Digest Law, Society \& Development 1(2007).

${ }^{13}$ H.W. Arthurs, "Law and Learning: Report to the Social Sciences and Humanities Research Council of Canada by the Consultative Group on Research and Education in Law," (Ottawa: Information Division, Social Sciences and Humanities Research Council of Canada, 1983), 63-71. Sebagaimana dikutip dalam Chynoweth, "Legal Research," 29-31.
} 
Perbedaan menarik direpresentasikan antara penelitian doktrinal dan interdisipliner yang diwakili oleh sumbu horisontal. Penelitian doktrinal (di sebelah kanan pada matriks) berkonsentrasi pada rumusan 'doktrin' melalui analisis kaidah hukum. Dalam keadaan yang normal dan umum kaidah hukum dengan mudah dapat ditemukan dalam undang-undang. Namun perlu diingat bahwa aturan hukum terkadang tidak memberikan pernyataan lengkap terhadap situasi tertentu.

Berbeda dengan penelitian ilmiah, baik ilmu-ilmu alam dan sosial, yang bergantung pada pengumpulan data empiris, baik sebagai dasar untuk teori-teori, atau sebagai sarana menguji mereka, sehingga validitas temuan penelitian ditentukan oleh proses investigasi empiris. Sebaliknya, keabsahan temuan penelitian doktrinal sama sekali tidak terpengaruh oleh dunia empiris. Karakter aturanaturan hukum bersifat normatif , hukum mendikte bagaimana individu harus berperilaku. ${ }^{14}$ Hukum sama sekali tidak berusaha untuk menjelaskan, memprediksi, atau bahkan untuk memahami perilaku manusia. Fungsi mereka satu-satunya adalah untuk menetapkan apa 'yang seharusnya'.

Dalam prakteknya, analisis doktrinal biasanya tetap merujuk ke beberapa referensi eksternal, dan faktor-faktor lain serta mencari jawaban yang konsisten dengan aturan hukum. Sebagai contoh, sebuah putusan hukum yang abu-abu atau ambigu sering dapat lebih mudah ditafsirkan bila dilihat dalam konteks sejarah dan sosial yang tepat, atau ketika penafsir memiliki pemahaman yang memadai tentang pengetahuan atau teknologi yang relevan. Ketika peneliti mulai mengambil dan menggunakan anasir-anasir asing dimasukkan dalam analisisnya, maka pada dasarnya penelitian mulai bergerak ke kiri sepanjang sumbu horisontal pada matriks, ke arah penelitian interdisipliner.

\section{Penelitian hukum murni dan terapan}

Sumbu vertikal bawah dari matriks mewakili perbedaan antara penelitian murni (pure), yang umumnya dilakukan oleh kalangan akademik dan sumbu atasnya adalah penelitian terapan (applied) yang biasanya dilakukan guna kebutuhan profesional para praktisi dan pembuat kebijakan publik. Dalam konteks penelitian hukum interdisipliner (di sebelah kiri matriks) di satu sisi, memperlihatkan perbedaan antara penelitian murni akademis tentang bagaimana bekerjanya hukum (bagian bawah) yang dia sebut sebagai 'penelitian fundamental' (fundamental research), dan penelitian yang dilakukan dengan tujuan tertentu (bagian atas). Penelitian dengan tujuan tertentu ini umumnya memfasilitasi perubahan masa depan dalam bidang hukum. Arthurs menggambarkan kategori yang terakhir ini sebagai 'penelitian reformasi hukum' (law reform research). Atau di UK lebih dikenal dengan istilah 'Hukum dalam konteks' (law in context) dan sekarang istilah yang lebih populer disebut dengan terma 'penelitian sosio-legal' (socio-legal research).

Dalam matriks ini terlihat jelas bahwa penelitian socio-legal berada pada ranah hukum terapan dan bersifat interdisipliner. Sementara pendekatan doktrinal fokus dengan hukum formal (law in books), penelitian sosio-legal berkonsentrasi pada hukum yang nyata (law in action). Pendekatan sosio-legal mengadopsi metode kualitatif dan kuantitatif dari berbagai ilmu-ilmu sosial dan melihat hukum sebagai fenomena sosial. Karakter cakupan metodologisnya semakin sulit untuk didefinisikan. Studi sosio-legal mencakup berbagai konteks disiplin ilmu, baik dalam ilmu-ilmu sosial maupun hukum, mengkaitkan hukum dengan dimensi sosiologis, politik dan ekonomi dari aktivitas manusia. Substansi dari penelitian sosial-legal mungkin dapat digambarkan sebagai apresiasi dari hubungan-hubungan interdisipliner dan aplikasi pelbagai perspektif tersebut terhadap masalah yang sedang diteliti. ${ }^{15}$ Beberapa peneliti mungkin cenderung tertarik dalam mengevaluasi pendekatan normatif terhadap beberapa fenomena sosial, ekonomi, dan budaya yang mempengaruhi perkembangan dan penerapan hukum. Sedangkan peneliti lainnya, mungkin tertarik pada keadilan sosial dan keadilan hukum ataupun institusi hukum dan hubungannya dengan proses peradilan.

\section{Dari Monodisipliner ke Interdisipliner}

Suatu saat, tepatnya 6 Januari 2016 beberapa yang lewat, 3 (tiga) sahabat yang pernah studi di Billy Blue College, Sidney, Australia, Jessica Kumala Wongso, Wayan Mirna Salihin dan Hanny kongkowkongkow minum kopi di Olivier Cafe, West Mall, Grand Indonesia Shopping Town, Jakarta Pusat. Mereka duduk di satu meja dan berbincang-bincang sambil menikmati minuman yang telah dipesan oleh Jessica. Seketika itulah tragedi terjadi ketika Mirna

\footnotetext{
${ }^{15}$ Michael Salter and Julie Mason, Writing Law Dissertations: An Introduction and Guide to the Conduct of Legal Research (London: Pearson Education Limited, 2007).
} 
mulai menyeruput es kopi Vietnam dan tidak lama berselang Mirna ambruk. Mirna dilarikan ke klinik mall, lalu dirujuk ke Rumah Sakit Abdi Waluyo dan meninggal disana. Berdasarkan pemeriksaan polisi, ditemukan Natrium Sianida dengan dosis yang cukup tinggi 15 gram per liter.

Sekitar 12 tahun yang lalu, kasus serupa juga menimpa salah satu pendekar hukum Indonesia, Munir Said Thalib. Dalam penerbangan dari Jakarta ke Negeri Belanda, Munir meregang nyawa dalam pesawat Garuda GA 974. Ironis, 2 (dua) jam menjelang pendaratan, nyawa Munir tidak bisa lagi diselamatkan. Setelah mendarat di Bandara Schipol Amsterdam, jenazah Munir diotopsi di Institut Forensik Nasional Belanda, ternyata ditemukan di tubuhnya 460 miligram arsenik. Walaupun terpidana Pollycarpus Budihari Prijanto, mantan pilot Garuda, mendapatkan pembebasan bersyarat pada tanggal 28 November 2014 setelah menjalani masa tahanan 8 (delapan) tahun dari 14 (empat belas) tahun yang seharusnya dijalani sebagai warga binaan, namun kasus Munir ini dianggap masih belum tuntas dan menyisakan sejumlah misteri.

Secara normatif hukum pidana, pembunuhan merupakan tindak pidana yang sangat serius. Pasal 340 Kitab Undang-Undang Hukum Pidana mengancam pembunuhan berencana dengan hukuman mati. Namun demikian, pasal tersebut tidak mempunyai arti apa-apa kalau unsur 'barang siapa' yang ada di dalamnya tidak berhasil diidentifikasi, begitu pula unsur-unsur lainnya. Dalam kasus Mirna, setelah lebih dari 3 (tiga) minggu polisi menerapkan scientific investigation baru pada tanggal 29 Januari 2016 pukul 23:00 polisi berhasil menetapkan siapa tersangka pembunuhnya. Sudah puluhan saksi fakta diperiksa. Beberapa saksi ahli sudah dimintakan keterangan ahlinya, dari pelbagai disiplin ilmu, seperti psikolog, ahli IT, dokter forensik, laborian forensik, ahli hukum pidana dan kriminolog, hingga barista. Kompleksitas fakta dalam setiap kasus hukum menuntut ilmu hukum untuk terus-menerus mengikuti percepatan perubahan secara dinamis. Dari ilustrasi tersebut, terbukti bahwa ilmu hukum doktrinal tidak bisa begitu saja mengambil alih kasus ini dan menerapkan instrumennya dengan pasal-pasal secara monodisipliner.

Demikian pula halnya dengan penelitian hukum doktrinal yang dikenal sebagai pendekatan hukum murni, atau pendekatan internal dengan menggunakan optik ilmu hukum yang bersifat dogmatik. Penelitian sejenis ini - yang disebut oleh Sunaryati Hartono sebagai 'penelitian monodisipliner, ${ }^{16}$ lebih banyak melihat ke dalam (internal) yang objek penelitian utamanya lebih difokuskan pada hukum positif (tekstual) sehingga cenderung kaku dan tertutup. ${ }^{17}$ Dalam beberapa dekade terakhir penelitian hukum doktrinal menerima kritik sangat keras keras dari banyak sarjana hukum. Menurut Vick, 'penelitian hukum doktrinal kaku, dogmatis, formalistik, dan tertutup (close-minded) ${ }^{18}$

Selain itu, Twining menekankan bahwa hukum sebagai disiplin akademis telah didominasi oleh 'monolitik ortodoksi yang sempit, konservatif, liberal, tidak realistis dan menjemukan'. ${ }^{19}$ Tidaklah mengherankan jika sarjana-sarjana hukum yang mengadopsi pendekatan doktrinal untuk penelitian hukum sama sekali tidak berdaya menjawab kritikankritikan dari mazhab non-doktrinal. Banyak sekali para sarjana hukum penganut pendekatan doktrinal yang biasanya melakukan penelitiaan de lege lata (the law as it exists) namun tiba-tiba bergeser kepada penelitian de lege ferenda (what the law should be/future law).$^{20}$ Akhirnya Cownie menyimpulkan: "Bersandar pada data yang telah dikumpulkan, menunjukkan bahwa hukum merupakan disiplin yang sedang berada pada tahapan transisi, bergerak menjauh dari analisis doktrinal tradisional kepada pendekatan interdisipliner yang lebih kontekstual." ${ }^{\text {"21 }}$ Bahkan Bradney secara lebih ekstrim menyatakan bahwa pendekatan doktrinal 'now entering its final death

\footnotetext{
${ }^{16}$ Hartono, Penelitian Hukum Di Indonesia Pada Akhir Abad Ke-20, 141.

${ }^{17}$ Anthon F. Susanto, Penelitian Hukum TransformatifPartisipatoris (Malang: Setara Press, 2015), 6.

${ }^{18}$ Douglas W. Vick, "Interdisciplinarity and the Discipline of Law," Journal of Law and Society 31, no. 2 (2004).

19 Ibid.

${ }^{20}$ Penelitian hukum doktrinal berkembang sejak abad kedua sebelum Masehi, dan mencapai tingkat yang sangat tinggi sejak abad ketiga setelah Masehi. Sepanjang Abad Pertengahan, penelitian hukum doktrinal ini dianggap sebagai 'disiplin ilmu', dimana pada saat itu 'interpretasi otoritatif' adalah kriteria utama untuk menilai status ilmiah dari suatu disiplin ilmu, bukan 'penelitian empiris'. Mark Van Hoecke, "Legal Doctrine: Which Method(S) for What Kind of Discipline?," in Legal Research Which Kind of Method for What Kind of Discipline?, ed. Mark Van Hoecke (Oxford and Portland, Oregon: Hart Publishing, 2011), 1.

${ }^{21}$ Fiona Cownie, Legal Academics: Culture and Identities (Oxford and Portland, Oregon: Hart Publishing, 2004), 197.
} 
throes. $^{22}$

Adapun inti teoritis yang selalu menjadi pusat kritik terhadap penelitian hukum doktrinal adalah positivisme hukum dan formalisme hukum. ${ }^{23}$ Dalam rangka memberikan kepastian hukum, positivisme hukum mengidentifikasi hukum sebagai peraturan perundang-undangan. Sebab hanya dengan cara mengidentifikasi hukum sebagai peraturan perundang-undangan dapat ditegakkan kepastian hukum. Dalam positivisme hukum dikenal asas fiksi hukum, dimana seseorang dianggap tahu tentang hukum, tentang apa yang boleh dan apa yang tidak boleh, sepanjang telah ditetapkan oleh penguasa yang berwenang. Hukum harus ditaati sepanjang telah ditetapkan sebagai peraturan perundang-undangan, terlepas dari penilaian apakah ia dianggap baik atau pun adil atau sebaliknya.

Dan puncak dari positivisme hukum adalah adanya anggapan bahwa positivisme hukum merupakan aliran paling akhir dan paling mutlak dalam ilmu hukum. Sikap ini kemudian berujung pada penutupan pintu kritik sehingga dialektika telah dianggap usai dan selesai. Aliran ini benarbenar menganggap ilmu dan praktik hukum telah final, dan tidak ada perkembangan baru di waktu mendatang. ${ }^{24}$ Dan sebuah monumen kemudian ditancapkan untuk menandai akhir penutupan pintu ijtihad ini dan usainya dialektika dalam ilmu dan praktik hukum, yaitu Kodifikasi. ${ }^{25}$

Dalam rambu seperti ini, peran hakim tidak lebih dari hanya sebagai corong atau terompet undang-undang (la bouche de la loi). Dalam pasal 21 Algemene Bepalingen van Wetgeving, misalnya menyatakan: "Tiada seorang hakim pun atas dasar

22 Ibid.

${ }^{23}$ Vitalij Levičev, "Holistic Perspective on Legal Research," in Integrating Social Sciences into Legal Research (Lithuania: Vilnius University, 2014), 218.

${ }^{24}$ Fenomena yang sama juga terjadi dalam sejarah perkembangan hukum Islam. Sekitar abad $5 \mathrm{H} / 11 \mathrm{M}$, para fuqaha mengeluarkan pendapat tentang larangan ijtihad dalam kajian fiqh. Setelah opini ini terbentuk dan disepakati, dia menjadi paradigma baru yang dikenal sebagai 'Penutupan Pintu Ijtihad' (insidad fii al-bab alijtihad). Fenomena ini berlangsung sedemikian lama hingga 7 (tujuh) abad. Lihat Wael B. Hallaq, Law and Legal Theory in Classical and Medieval Islam (Burlington: Ashgate, 1994).

${ }^{25}$ Dalam sejarah hukum Islam, salah satu dampak penutupan pintu ijtihad adalah perkembangan fiqh yang stagnan. Fiqh hanya cenderung memperjelas (syarakb), memahami dan meringkas (ikhtisyar) kitab-kitab lama. peraturan umum atau penetapan berbak memutus dalam perkara-perkara yang tunduk pada putusannya." Dengan kata lain, hakim tidak boleh menciptakan hukum, melainkan hanya menerapkan hukum, tanpa harus menilai apakah putusannya adil atau tidak. Hal ini senada dengan jargon Montesquieu dalam L'Esprit des lois: les juges de la nation ne sont que la bouche qui pronounce les paroles de la lois: des entres inanimes qui n'en peuvent modere ni la force ni la rigueur (para hakim hanyalah mulut yang mengucapkan kata-kata undang-undang; mereka adalah makhluk yang tidak bernyawa yang tidak boleh melemahkan kekuatan dan kekerasan undang-undang). Secara lebih kongkret, positivisme hukum ini sangat kental dirasakan dalam ranah hukum pidana. Hal ini ditentukan dalam Pasal 1 ayat (1) Kitab UndangUndang Hukum Pidana: "Tiada suatuperbuatan dapat dipidana kecuali atas dasar peraturan berkekuatan undangundang yang terlebih dabulu ada dari perbuatan tersebut."

Penelitian hukum monodisipliner yang dibalut dengan paradigma positivisme ini sangat terbatas dan sempit. Dikatakan sempit karena hanya berkutat di seputar issu hukum, sedangkan realitas di luar hukum, atau bahkan hukum pun sepanjang tidak formal, tetap dianggap bukan hukum. Hukum direduksi pengertiannya hanya pada peraturan perundang-undangan. ${ }^{26}$ Penelitian jenis ini juga dikritisi sebagai penelitian yang kering dari nilai-nilai sosial, moralitas dan aspek-aspek falsafati. ${ }^{27}$ Menurut Joeni Arianto Kurniawan, kajian hukum positif yang positivistik akan benarbenar terasakan a sosial atau begitu terisolir dari permasalahan-permasalahan sosial yang ada hanya karena permasalahan tersebut tidak ada aturan hukumnya atau diatur tetapi tidak sesuai dengan realitas yang ada di masyarakat. ${ }^{28}$

Pada dasarnya konstelasi penelitian hukum di Indonesia tidak terlepas dari sejarah pemikiran hukum yang berkembang selama ini. Menurut Dimyati $^{29}$, di era tahun 1945-1970-an pemikiran

\footnotetext{
${ }^{26}$ Susanto, Penelitian Hukum Transformatif-Partisipatoris, 2122.

${ }^{27}$ Ibid., 24.

${ }^{28}$ Joeni Arianto Kurniawan, "Pluralisme Hukum Dan Urgensi Kajian Socio-Legal Menuju Studi Dan Pengembangan Hukum Yang Berkeadilan Sosial," in Simposium Nasional dan Workshop Sosio Legal "Rekonstruksi Bantuan Hukum yang Menjamin Access to Justice" (Universitas Brawijaya, Malang, Jawa Timur2013), 16-17.

${ }^{29}$ Khudzaifah Dimyati, Teorisasi Hukum: Studi Tentang Perkembangan Pemikiran Hukum Di Indonesia 1945-1990 (Surakarta: Universitas Muhammadiyah Surakarta Press,
} 
hukum di Indonesia masih sangat terfokus pada aspek normatif dan memiliki komitmen yang kuat pada hukum adat dengan tokoh-tokoh utama seperti Soepomo dan Hazairin. Periode selanjutnya 1970-1990-an pemikiran hukum mulai bersifat transformatif dengan tokoh-tokohnya seperti Mochtar Kusumaatmadja, Satjipto Rahardjo dan Sunaryati Hartono. Dalam periode ini ada dua aliran utama, yaitu (1) aliran Mochtar Kusumaatmadja yang secara nyata menggunakan teori 'hukum sebagai sarana perubahan sosial' (tool of social engineering) yang dipakai secara luas dalam pembuatan kebijakan pada pemerintah Orde Baru, dan (2) aliran hukum progresif dengan pendukungnya Satjipto Rahardjo, dimana beliau percaya bahwa hukum baru bisa efektif jika mencerminkan kondisi masyarakat (legal realist) dan harus bisa mengubah masyarakat secara progresif menuju kondisi yang lebih baik. Perkembangan pemikiran hukum pasca reformasi tahun 1998, justru semakin menguatkan posisi dan pemikiran Satjipto Rahardjo dengan pendekatan sosiologi hukum dan hukum progresif-nya, dan T.O. Ihromi yang menggunakan pendekatan antropologi hukum, atau para tokoh-tokoh pakar hukum muda seperti Sulistyowati Irianto yang giat mendorong kajian socio-legal studies.

Dalam kaitan dengan penelitian hukum Islam, metodologi studi hukum Islam yang selama ini ada, juga terkesan semata-mata bersifat normatif dan sui-generis. Hal ini disebabkan fokus kajiannya kebanyakan analisis terhadap teks transendental. Kesan di atas mengindikasikan bahwa hukum Islam hanya dapat dicari dan diderivasi dari teks-teks wahyu saja (law in book), sementara realitas sosial empiris yang hidup dan berlaku di masyarakat (living law) kurang mendapatkan tempat yang proporsional dalam metodologi penelitian hukum Islam konvensional..$^{30}$ Miskinnya analisis sosial empiris (lack of empiricism) tersebut disinyalir oleh banyak pihak menjadi salah satu kelemahan mendasar dari cara berpikir dan pendekatan yang ada dalam metodologi penelitian hukum Islam saat ini. ${ }^{31}$

Pendekatan sosial empirik sebenarnya sudah mulai digagas oleh al-Gazali dan dikuatkan oleh asy-Syatibi, namun kebanyakan karya-karya $\underline{\text { mereka masih memusatkan kajiannya pada }}$

2004).

${ }^{30}$ Hasyim Kamali, Principles of Islamic Jurisprudence (Cambridge: The Islamic Texts Society, 1991).

${ }^{31}$ Abu Sulaiman, Towards an Islamic Theory of International Relation: New Direction for Metodology and Thought (Virginia: tnp, 1994), 87. analisis doktrin normatif tekstual. Hal yang sama juga telah diupayakan oleh para pakar setelahnya, namun kurangnya analisis empiris dan kecenderungan menggunakan pendekatan tekstual dalam metodologi penelitian hukum Islam masih menjadi momok yang tidak terselesaikan. Dengan demikian, secara metodologis, penelitian hukum Islam masih menyisakan ruang kosong antara dirinya dengan realitas yang ada di sekelilingnya. ${ }^{32}$

Sejatinya, hukum dapat dipelajari baik dari perspektif ilmu hukum atau ilmu sosial, maupun kombinasi diantara keduanya. Studi sosio-legal merupakan kajian terhadap hukum dengan menggunakan pendekatan ilmu hukum maupun ilmu-ilmu sosial. Kajian sosio-legal biasanya digunakan sebagai konsep payung. Kajian ini mengacu pada semua bagian dari ilmu-ilmu sosial yang memberikan perhatian pada hukum, proses hukum atau sistem hukum. Salah satu karakteristik penting dari sebagian besar kajian sosio-legal adalah sifat kajiannya yang multi atau interdisiplin. Ini berarti perspektif teoretis dan metodologi-metodologi dalam kajian sosio-legal disusun berdasarkan penelitian yang dilakukan dengan berbagai disiplin yang berbeda. Disiplin keilmuan yang digunakan sangat beragam, mulai dari sosiologi dan antropologi sampai ilmu politik, administrasi publik, dan ekonomi, tetapi juga psikologi dan kajian-kajian pembangunan. Pada prinsipnya, tidak ada batasan yang jelas atas disiplin ilmu yang dapat digunakan..$^{33}$ Namun suatu hal yang pasti, walaupun persinggungan pendekatan socio legal dengan ilmu-ilmu sosial lainnya sangat dominan, namun bome-based mereka tetaplah hukum sebagai tumpuan awal. Dan mayoritas para peneliti socio-legal memang berasal dari dari kalangan

\footnotetext{
${ }^{32}$ Kawasan studi Islam Indonesia yang digelar di IAIN/ STAIN selama ini berpijak pada keputusan Menteri Agama Nomor 110 tahun 1982 yang meliputi bidang; (1) Al-Quran-Hadis, (2) Pemikiran dalam Islam, (3) Fiqh/Hukum Islam dan Pranata Sosial, (4) Sejarah dan Peradaban Islam, (5) Bahasa, (6) Tarbiyah Islamiyah, (7) Dakwah Islamiyah, (8) Perkembangan Modern Dunia Islam dan beberapa disiplin ilmu sebagai cabangnya. Disiplin ilmu yang dikembangkan di PTAI mengerucut pada pembidangan ilmu tersebut. Sejak dekade terakhir ini dalam mengapresiasi perubahan IAIN/STAIN menjadi UIN banyak pakar yang menawarkan perluasan studi Islam dengan mencari titik temu antara ilmu-ilmu keislaman dengan ilmu-ilmu umum.

33 Adriaan W. Bedner et al., eds., Kajian Sosio-Legal (Denpasar: Pustaka Larasan: Jakarta: Universitas Indonesia, Universitas Leiden, Universitas Groningen,2012), vi.
} 
sarjana hukum. ${ }^{34}$

\section{Kesimpulan}

Penelitian hukum doktrinal dalam pendidikan tinggi akan lebih diperkaya jika menyediakan sedikit ruang bagi penelitian hukum sosio-legal yang bersifat interdisipliner. Pendekatan ini akan membantu menemukan dan menjelaskan keterkaitan hukum dan masyarakat. Dengan demikian diharapkan akan lahir para sarjana profesional yang tidak hanya paham tentang ilmu hukum, tetapi juga insan hukum yang dapat berfungsi maksimal karena paham tentang sendisendi keadilan masyarakatnya sendiri.

Secara khusus, kegagalan gerakan Pembangunan Hukum di banyak negara berkembang, menunjukkan bahwa dalam konteks tertentu penelitian doktrinal tidak dapat menjawab berbagai persoalan keadilan yang menyangkut kaum marjinal. Banyak persoalan kemasyarakatan yang sangat rumit dan tidak bisa dijawab secara tekstual dan monodisiplin, dan dalam situasi seperti ini penjelasan yang lebih mendasar dan mencerahkan bisa didapatkan secara interdisipliner. Oleh karenanya dibutuhkan suatu pendekatan hukum yang bisa menjelaskan hubungan antara hukum dan masyarakat. Dan pendekatan socio-legal merupakan salah satu alternatifnya.

\section{Referensi}

Arthurs, H.W. . "Law and Learning: Report to the Social Sciences and Humanities Research Council of Canada by the Consultative Group on Research and Education in Law." Ottawa: Information Division, Social Sciences and Humanities Research Council of Canada, 1983.

Banakar, Reza, and Max Travers, eds. Theory and Method in Socio-Legal Research. Oxford and

\footnotetext{
${ }^{34}$ Reza Banakar and Max Travers, eds., Theory and Method in Socio-Legal Research (Oxford and Portland, Oregon: Hart Publishing,2005), 1. Bandingkan dengan sekolah-sekolah hukum di Negeri Belanda i memperlihatkan bagaimana kedudukan studi hukum alternatif, baik studi yang klasik, maupun studi sosio-legal berumah di fakultas hukum di Belanda. Lihat Sulistyowati Irianto, "Memperkenalkan Studi Sociolegal Dan Implikasi Metodologisnya," in Metode Penelitian Hukum : Konstelasi \& Refleksi, ed. Sulistyowati Irianto and Shidarta (Jakarta.: Yayasan Obor Indonesia, 2011), 185.
}

Portland, Oregon: Hart Publishing, 2005.

Becher, T. "Towards a Definition of Disciplinary Cultures." Studies in Higher Education 6 (1981): 109-22.

Bedner, Adriaan W., Sulistyowati Irianto, Jan Michiel Otto, and Theresia Dyah Wirastri, eds. Kä̈an Sosio-Legal. Denpasar: Pustaka Larasan: Jakarta: Universitas Indonesia, Universitas Leiden, Universitas Groningen, 2012.

Chynoweth, Paul "Legal Research." In Advanced Research Methods in the Built Environment, edited by Andrew Knight and Leslie Ruddock. Chichester, West Sussex, United Kingdom ; Ames, Iowa: Wiley, 2008.

Cownie, Fiona. Legal Academics: Culture and Identities. Oxford and Portland, Oregon: Hart Publishing, 2004.

Dimyati, Khudzaifah. Teorisasi Hukum: Studi Tentang Perkembangan Pemikiran Hukum Di Indonesia 1945-1990. Surakarta: Universitas Muhammadiyah Surakarta Press, 2004.

Dobinson, Ian, and Francis Johns. "Qualitative Legal Research." In Research Methods for Law, edited by Mike McConville and Wing Hong Chui, 16-45. Edinburgh Edinburgh University Press, 2007.

Hallaq, Wael B. Law and Legal Theory in Classical and Medieval Islam. Burlington: Ashgate, 1994.

Hartono, Sunaryati. Penelitian Hukum Di Indonesia Pada Akbir Abad Ke-20. Bandung: Alumni, 1994.

Hasyim Kamali. Principles of Islamic Jurisprudence. Cambridge: The Islamic Texts Society, 1991.

Hoecke, Mark Van. "Legal Doctrine: Which Method(S) for What Kind of Discipline?" In Legal Research Which Kind of Method for What Kind of Discipline?, edited by Mark Van Hoecke. Oxford and Portland, Oregon: Hart Publishing, 2011.

Ibrahim, Johnny. Teori Dan Metodologi Penelitian Hukum Normatif. Malang: Bayumedia, 2006.

Irianto, Sulistyowati. "Memperkenalkan Studi Sociolegal Dan Implikasi Metodologisnya." In Metode Penelitian Hukum : Konstelasi \& Reflekesi, edited by Sulistyowati Irianto and Shidarta. Jakarta.: Yayasan Obor Indonesia, 2011. 
Irianto, Sulistyowati. "Praktik Penelitian Hukum: Perspektif Sosiolegal." In Metode Penelitian Hukum: Konstelasi \& Refleksi, edited by Sulistyowati Irianto and Shidarta. Jakarta: Yayasan Obor Indonesia, 2011.

Kurniawan, Joeni Arianto. "Pluralisme Hukum Dan Urgensi Kajian Socio-Legal Menuju Studi Dan Pengembangan Hukum Yang Berkeadilan Sosial." In Simposium Nasional dan Workshop Sosio Legal "Rekonstruksi Bantuan Hukum yang Menjamin Access to Justice". Universitas Brawijaya, Malang, Jawa Timur, 2013.

Levičev, Vitalij. "Holistic Perspective on Legal Research." In Integrating Social Sciences into Legal Research. Lithuania: Vilnius University, 2014.

Marzuki, Peter Mahmud. Penelitian Hukum (Edisi Revisi). 7 ed. Jakarta: Prenadamedia Group, 2014.

McConville, Mike, and Wing Hong Chui, eds. Research Methods for Law. Edinburgh: Edinburgh University Press, 2007.

Salter, Michael, and Julie Mason. Writing Law Dissertations: An Introduction and Guide to the Conduct of Legal Research. London: Pearson Education Limited, 2007.

Simarmata, Rikardo. "Socio-Legal Studies Dan Gerakan Pembaharuan Hukum." Digest Law, Society \& Development 1 (2007).

Soekanto, Soerjono. Pengantar Penelitian Hukum. Jakarta: UI-Press, 2014.

Soekanto, Soerjono, and Sri Mamudji. Penelitian Hukum Normatif: Suatu Tinjauan Singkat. 3 ed. Jakarta: Rajawali Press, 1990.

Sulaiman, Abu. Towards an Islamic Theory of International Relation: New Direction for Metodology and Thought. Virginia: tnp, 1994.

Susanto, Anthon F. Penelitian Hukum TransformatifPartisipatoris. Malang: Setara Press, 2015.

Tamanaha, Brian Z. Realistic Socio-Legal Theory Pragmatism and a Social Theory of Law. New York: Oxford University Press, 1997.

Vick, Douglas W. "Interdisciplinarity and the Discipline of Law." Journal of Law and Society 31, no. 2 (2004): 163-93.

Wignjosoebroto, Soetandyo. Hukum: Paradigma, Metode Dan Masalah. Jakarta: ELSAM dan HUMA, 2002.
Wignjosoebroto, Soetandyo. "Penelitian Hukum Dan Hakikatnya Sebagai Penelitian Ilmiah." In Metode Penelitian Hukum: Konstelasi Dan Refleksi, edited by Sulistyowati Irianto and Shidarta, 83-120. Jakarta: Yayasan Pustaka Obor Indonesia, 2013.

Wignjosoebroto, Soetandyo. "Ragam-Ragam Penelitian Hukum." In Metode Penelitian Hukum: Konstelasi Dan Refleksi, edited by Sulistyowati Irianto and Shidarta, 121-41. Jakarta: Yayasan Pustaka Obor Indonesia, 2013.

Wignjosoebroto, Sutandyo. "Tentang Teori, Konsep Dan Paradigma Dalam Kajian Tentang Manusia, Masyarakat Dan Hukumnya." (2015), https://soetandyo.files.wordpress. com/2010/09/teori_hukum_soetandyo. pdf. 